\title{
HOW WILDFIRES AFFECT SOIL PROPERTIES. A BRIEF REVIEW
}

\author{
L.M. ZAVALA, R. DE CELIS, A. JORDÁN* \\ MED-Soil Researach Group. Dpto. de Cristalografía, Mineralogía y Química Agrícola \\ Universidad de Sevilla. c/ Profesor García González 1, 14012, Sevilla, Spain.
}

\begin{abstract}
Wildfires may produce several changes in the short- and longterm in the landscape and in the soil system. The magnitude of these changes induced by fire in the components of ecosystems (water, soil, vegetation and fauna) depends on fire properties (fire intensity and severity) and environmental factors (vegetation, soil, geomorphology, etc.). The most important impacts on soils in the short-term are the reduction of vegetation cover (which increases soil erosion risk), the deposition of ash after combustion of biomass, the induction of enhancement of water repellency and changes in the structure and soil components. Combustion of biomass and soil organic matter also results in the release of gases and other pollutants into the atmosphere. Similarly, the changes induced by fire on the biological soil components (vegetation, animals and soil microorganisms) may occur rapidly and produce a large-scale response. The long-term effects of fire on soils and water may well persist for relatively short periods (hours, days or months), long (years or tens of years), or be permanent depending on the severity of fire and fire regime. Some of these effects are a consequence of the relationship between fire, soil, hydrology and nutrient cycling.
\end{abstract}

\section{Cómo afectan los incendios a las propiedades del suelo. Una breve revisión}

RESUMEN. Los incendios forestales pueden producir varios cambios a corto y largo plazo en el paisaje y en el sistema suelo. La magnitud de estos cambios inducidos por el fuego en los componentes de los ecosistemas (agua, suelo, vegetación y fauna) depende de las propiedades del incendio (intensidad y severidad del fuego) y ambientales (vegetación, suelos, geomorfología, etc.) Los impactos más importantes de los suelos en el corto plazo son la reducción de la cubierta vegetal (que aumenta el riesgo de erosión del suelo), la deposición de cenizas después de la combustión de la biomasa, la inducción de la mejora de la repelencia al agua y los cambios en la estructura y componentes del suelo. La combustión de la materia orgánica del suelo y la biomasa también se traduce en la emisión de gases y otros contaminantes a la atmósfera. Del mismo modo, los cambios inducidos por el fuego en los componentes biológicos del suelo (vegetación, animales y microorganismos del suelo) pueden ocurrir rápidamente y producir una respuesta a gran escala. Los efectos a largo 
plazo de los incendios en los suelos y el agua y pueden persistir durante períodos relativamente cortos (horas, días o meses), largos (años o decenas de años), o ser permanente dependiendo de la severidad del fuego y el régimen de incendios. Algunos de estos efectos son una consecuencia de la relación entre el fuego, la hidrología y el ciclo de nutrientes.

Key words: forest fires, forest soils, soil degradation, soil chemical properties, soil physical properties.

Palabras clave: incendios forestales, suelos forestales, degradación del suelo, propiedades químicas del suelo, propiedades físicas del suelo.

Received 15 November 2013

Accepted 20 February 2014

*Corresponding author: MED-Soil Research Group. Universidad de Sevilla. c/ Profesor García González 1, 14012, Sevilla, Spain. E-mail: ajordan@us.es

\section{Introduction}

Fire is one of the most important causes of impacts in ecosystems (Eiten, 1992; Neary et al., 1999; Bond and Keeley, 2005; Certini, 2005; Neary et al., 2005; Kutiel, 2006). In Mediterranean areas, fires are recurrent and frequent during summer. Mediterranean climate is characterized by dry and high temperatures exceeding $40^{\circ} \mathrm{C}$ (Moreno and Oechel, 1995; De la Rosa et al., 2008). Concerns about forest fires and their impacts in the Mediterranean region began in the 1960s, when an exponential increase in the number of fires was observed (Moreno et al., 1998; Pausas, 2004) as a result of abandonment of marginal areas and land use change, usually in mountainous areas (Margaris et al., 1996).

Fire can induce physical, chemical and biological impacts on soil properties. Sustainability and recovery of fire-affected soils depend both on the chemical, physical and biological as fire severity (Neary et al., 1999). Fire impacts on the soil are basically of two types (Neary et al., 1999): direct, as a result of the combustion of organic matter and the temperatures reached in the soil, and indirect, as a result of changes in other components of the ecosystem, such as reduced vegetation cover, charred litter or the deposition of partially burned plant residues and ash (Cerdà and Doerr, 2008) or changes in flora (Trabaud, 2000; Pausas and Verdú, 2005). The severity of these impacts depends heavily on fire intensity, duration and frequency (Inbar et al., 1998; Flannigan et al., 2000; Robichaud et al., 2000). Low intensity fires, during which high temperatures are not reached and that will not unduly affect vegetation cover, do not cause major impacts, and, in most cases, will affect only the very few first millimeters of soil depth. Prolonged, recurrent, or high-intensity fires, in which high temperatures consume most of the vegetation cover, may result in differences in the soil functioning (Doerr et al., 2006). In these cases, the period of time required for soils to turn back to the initial conditions may be very long, or changes become permanent. In this article we review the effects of fire on [i] biological, [ii] chemical [iii] and physical properties of Mediterranean forest soils. 


\section{Fire intensity and fire severity}

In studies on the effects of fire on ecosystems, it is common to use the terms fire "intensity" and "severity". However, these two terms are not the same (a very interesting review of both concepts was conducted by Keeley, 2009). Fire intensity refers to the fuel consumption rate on the ground and therefore the energy release rate (Albini, 1976; Alexander, 1982; Chandler et al., 1983). Although the rate at which energy is transmitted through the soil depends on its intrinsic properties, the residence time of high temperature has a great importance for the extent of changes induced in the soil (Campbell et al., 1977; Frandsen and Ryan, 1986).

Even when fire affects soil directly (which does not occur during a crown fire, for example), only a small portion of the thermal energy released by the fire is transmitted to the ground (Packham and Pompe, 1971). Therefore, fire intensity is not necessarily a good measure of the amount of energy transmitted to soil, not a good indicator of physical, chemical and biological changes, as fire may cause little or no impact on the soil surface. However, the combustion of organic matter or vegetation allows increased residence time of high temperatures and transmitting a high amount of energy to the ground.

Because the amount of heat energy released or transmitted to soils cannot be measured in the case of natural fires, fire intensity is a parameter difficult to study. For this reason, some authors have proposed the use of fire severity (Simard, 1991; Agee, 1993; DeBano et al., 1998; Ryan, 2002). In general, fire severity is an indirect measure of the magnitude of changes in the soil or the ecosystem as a result of a fire. Evaluating fire severity should not take into account only the effect on soils, since the intensity of the disturbance in the ecosystem may be very high despite a low impact on soil (Vasander and Lindholm, 1985; Frandsen and Ryan, 1986; Hartford and Frandsen, 1992; Ryan, 2002). Most systems for classifying fire severity are arbitrary, but are selected from previous experience, and implicitly recognize that even in the case of high severity fires, large spatial variability exists due to the irregularity of the medium or influencing factors (fuel, weather variables or spot morphology). Fire severity can be classified according to certain criteria such as the amount of fuel consumed, the properties of these fuels (height, diameter of non-consumed branches or stems, water and mineral contents) the effect of these fuels in fire during different stages of burning or heat transfer and its subsequent effects (color soil and ash textural changes and loss of organic matter, for example).

Moreover, the effect of fire is usually very limited in depth because of poor thermal conductivity, being negligible from the first few inches in most cases. The thickness of the layer of soil affected by the fire is directly related to the amount of exposed mineral soil, the depth of penetration of thermal energy, the depth to which a hydrophobic layer is formed or the depth at which other chemical alterations occur, as well as the depth to which the microbial population is affected.

\section{Effects of wildfires on Mediterranean soils}

Geological evidence such as the presence of carbon in sediments, show that fire has been present since 400 million years ago (early Devonian), with changing frequency and intensity 
according to atmospheric oxygen levels and climate (Scott, 2000, 2009; Bodí et al., 2012a). The human impact on the fire regime became significant in the Neolithic (approximately between $10200 \mathrm{BC}$ and $2000 \mathrm{BC}$ ), with the beginning of farming, and when fire was used as a tool for the management of large areas. It is estimated that this practice was established about 7000 years ago, as proved by archaeological and palynological analysis from different areas in Europe, and has continued until very recently in the Mediterranean basin (Pausas et al., 2008; Pausas and Keeley, 2009). Previously to farming activity, the Mediterranean forest was formed mainly of oaks, and conifers were less abundant and stayed confined to the hillsides. The settlement of farming populations induced the rapid disappearance of oak forests in the most fertile areas, while, in contrast, conifers spread through abandoned agricultural areas and were favored by reafforestation. Until the mid-twentieth century in Spain, Portugal and other Mediterranean countries, forest management consisted of a sometimes abusive use of forest resources, burning vegetation for growing cereals, fruit or olives. The result was a patched and diverse landscape with low risk of fire, which was quickly suppressed by the people who lived and worked in rural areas (Bodí et al., 2012a). In the 1960s, industrialization and rural migrations in the European Mediterranean caused the abandonment of rural areas and traditional practices (grazing, maintenance of fences and forest roads or vegetation management), increasing the risk of fire (Bodí et al., 2012a). Land use changes and reforestation with fast-growing but highly flammable species (such as pines or eucalyptus) have clearly contributed to increased risk of fire (Fernández et al., 2004; Shakesby, 2011).

\subsection{Effects on soil biotic components}

One major effect of forest fires is the strong reduction of vegetation cover. Although most wildfires show a low severity (Agee, 1993), recurrent high-severity fires can occasionally be observed in many ecosystems (Paine et al., 1998; Pérez-Cabello et al., 2010). Recurrent fires can affect vegetation in the short-term (Bond and van Wilgen, 1996), but their effects may vary greatly depending on the characteristics of the species and reproductive strategies (Noble and Slatyer, 1980; Bond and van Wilgen, 1996). According to this, four major groups of plants can be found: resprouting, seeders, facultative resprouting and, finally, species unable to sprout, or with seeds which cannot withstand high temperatures. The latter may disappear temporarily after a wildfire, but may recolonize the burned area from the unaffected borders (Pausas, 2004; Lloret and Zedler, 2009; Bodí et al., 2012a). Resprouting is one of the best pyroresistance mechanisms. Resprouting plants have developed low-flammable thick bark structures which act as thermal insulators protecting aerial parts (as in Quercus suber) or protects the underground parts able to resprout (as in Erica australis). Species such as Quercus coccifera show a great capacity for resprouting after fire and a large root system that allows rapid recovering. There are non-resprouting shrubs with persistent soil seed banks which resist intense heating, as Cistus or Ulex species. In other cases, seeds are stimulated to germinate by products of combustion like smoke or ash (e.g., Rhamnus alaternus, Alnus glutinosa, Cistus incanus, Clematis vitalba) (Crosti et al., 2006; Paula et al., 2006). However, if the period between consecutive fires is not enough for individuals to reach adulthood, or if fires are highly recurrent, the seed bank may become exhausted (Pausas, 2004). After fire, short-life herbaceous plants may cover the 
burned area quickly, together with resprouting shrubs. Herbaceous cover may peak in 1-5 years, and then growth rate slows (Ferran and Vallejo, 1992; Ferran and Vallejo, 1998). Resprouting shrubs usually grow very fast due to well-developed root systems, able to capture water and nutrients.

The recurrence of the fires has favored the formation of ecosystems very different from those expected under the climatic conditions of the Mediterranean area. As a consequence, species with fire resistance mechanisms endure and different morphologies and reproductive strategies adapted to fire are developed (Pyne, 2001; Pausas and Verdú, 2005; Pausas et al., 2008; Pérez-Cabello et al., 2010). This is the case of some pyrophytic plants, as species of Ericacea or Fabaceae.

Post-fire high biological activity and abundance of symbiosis between plants, fungi and bacteria are observed in hardly damaged areas, which denotes certain compatibility and ease of recolonization. Chemical changes (increased $\mathrm{pH}$ and release of nutrients from ash) stimulate the increase of microbial population, even higher than before burning (Mataix-Solera and Guerrero, 2007). High biological activity and symbiotic relations between plants and algae occur during the first rains after burning (Mataix-Solera and Guerrero, 2007; Bodí et al., 2012a).

Soil fauna is also affected by fire, which may be drastically disturbed (Cairney and Bastias, 2007; Metz and Dindal, 1980) at the soil surface and, occasionally, at deeper soil layers by combustion of root structures. Food sources are drastically reduced immediately after fire, limiting the available resources for soil fauna (Gongalsky et al., 2006; Moretti et al., 2006; Gongalsky et al., 2008; Malmström et al., 2009), although not all animals are affected equally (Bengtsson, 2002). The recovery of soil organisms after fire is probably related to the density of the plant cover and the thickness of the organic layer remaining after the fire (Gongalsky and Persson, 2013). Recovery can occur from neighboring unburned areas (Bezkorovainaya et al., 2007), or from low-severity burned patches (Gongalsky and Persson, 2013).

Different groups of microorganisms show different strategies against disturbances. Fungi, for example, often show greater resistance than bacteria (Dunn et al., 1985), although bacteria can recover faster (Guerrero et al., 2000; Guerrero et al., 2005; BárcenasMoreno and Baath, 2009; Ponder et al., 2009; Bárcenas-Moreno et al., 2011). However, if fire intensity is sufficiently high, soil may become partially sterilized (Pietikäinen and Fritze, 1995). After this phase, the increased nutrient pool allows the rapid proliferation of bacteria. When the substrate becomes limiting again, microbial activity decreases, but biomass continues to increase, until population stabilizes progressively after revegetation (Bárcenas-Moreno et al., 2011).

\subsection{Effects of fire on physical soil properties}

\subsubsection{Colour}

Color changes caused by fire may be very significant and are caused either to accumulation of ash (which can display a color range from black to white depending on 
the greater or lesser severity of the fire), the redness produced by alteration of the iron oxides, to blackening or combustion of organic matter. As a rule, it has been observed under laboratory conditions the redness increases with temperature, primarily in the range of 300 to $500^{\circ} \mathrm{C}$, due to the transformation of iron oxides into hematite and maghemite (Terefe et al., 2005, 2008).

Carbonized materials affecting the color of soil for long time periods (Schmidt et al., 1999). For these reasons, changes in the color of soil can be used as an indicator of fire severity. In iron-rich soils, Ketterings et al. (2000) observed that Munsell hue became more yellow, while value and chroma decreased after short-term exposure to temperatures of $300-600^{\circ} \mathrm{C}$, or redness does not appear until after 45 minutes of exposure to temperatures of $600^{\circ} \mathrm{C}$.

Several authors (Hajdas et al., 2007; Eckmeier et al., 2010, 2013; Pereira et al., 2013a, 2013b) have shown that black colour in burned soils is a consequence of charred litter and black char (black ash produced by incomplete combustion; Robinson, 1991). The dark color reduces the albedo of the soil surface, so burned soils have a high tendency to heat and therefore increase the evaporation rate.

\subsubsection{Ash}

The chemical composition of ash sedimented after a wildfire commonly includes $\mathrm{Ca}, \mathrm{Mg}, \mathrm{K}, \mathrm{Si}$ and $\mathrm{P}$. In some cases, ash may also include significant amounts of Al, Mn, Fe and Zn (Etiègni and Campbell, 1991; Khanna et al., 1994). The exact proportion of each element depends mainly on the composition of fuel and temperatures reached during burning (Misra et al., 1993; Demeyer et al., 2001).

Different conditions of combustion and fuel generate a variable pattern of ash distribution. This variability increases with time due to wind and runoff erosion, especially in steep slopes. A heterogeneous pattern of soil protection is obtained after fire, which varies with compaction and redistribution of ash. This means that soil is differentially exposed to erosion agents and other processes (Pérez-Cabello et al., 2012; Pereira et al., 2013b). The thickness of the ash layer depends on fire severity: thin ash layers are observed after low-severity fire, while thick ash layers are observed after highseverity fire due to the consumption of larger amounts of fuel. The amount of charred litter and ash released after fire seems to be a key factor in reducing post-fire soil erosion risk in a short period ranging between hours and months (Cerdà, 1998; De Luis et al., 2003; Cerdà and Doerr, 2008; Zavala et al., 2009). The time period during which ash remain on the soil surface may vary depending on external agents as rainfall, runoff or wind and properties of ash (Cerdà and Doerr, 2008). Properties of ash vary according to the plant species burned, the amount of fuel, fuel moisture content, temperature peaks reached and residence time of soil temperatures (Ulery et al., 1993; Pereira et al., 2009; Úbeda et al., 2009).

The effects of ash on postfire runoff and erosion depend [i] on its physical and mineralogical properties: particle size, porosity, calcium carbonate content, or water repellency (Larsen et al., 2009; Woods and Balfour, 2010; Bodí et al., 2012b), [ii] on physicochemical changes in ash after the interaction with the atmosphere and water 
(Etiegni and Campbell, 1991), the thickness of the ash layer (Woods and Balfour, 2010), and [iii] lithology and soil type of the area affected by the fire (Bodí et al., 2012b; Larsen et al., 2009; Woods and Balfour, 2010).

After fire, ash is an important source of nutrients. High-severity fires reduce fuel on the surface to small particles that are easily transported and incorporated into the soil profile. Therefore, it is very probable that ash produced at higher temperatures during burning induce effects on soil properties, because the smaller particles are more easily incorporated into the soil deeper layers. This process is also conditioned by the soil properties, especially the texture (Woods and Balfour, 2010).

Frequently, the effect of this input of nutrients is ephemeral or short-termed (Pereira et al., 2009), as soluble minerals are quickly leached or lost with runoff flow, especially in steep slopes or in areas where the uptake of nutrients by vegetation is poor or soil properties do not allow the retention of nutrients after a rapid saturation of the cation exchange complex, for example (Neary et al., 1999; Cerdà and Bodí, 2007). Studies carried out by Pereira et al. (2013a, 2013b) in Lithuania show that the greatest loss occurred in the first days after fire, as a result of rainfall. They also found that loss of ash was more important in high-severity burned areas, and was caused by erosion and compaction ash layer (Pereira et al., 2013b). In Mediterranean areas, a significant ash layer has been observed during periods ranging between a few days (Cerdà and Doerr, 2008; Zavala et al., 2009) and some years (Ruiz del Castillo, 2000).

The ash capacity to protect soil will depend on the topography of the burned area, weather conditions during the post-fire and thick of ash (Cerdà and Doerr, 2008; Pereira et al., 2010). The study of the thickness of the ash layer shows the degree of soil protection in the period immediately after the fire, and how it changes in space and time (Pereira et $a l ., 2013 c)$. Several studies have been conducted on the effects of ash on soil properties in burned areas which consider the thickness of the ash layer as a key to understand the impact on soil fertility on the evolution of ecosystems in the post-fire (Mallik et al., 1984; Leighton-Boyce et al., 2007; Cerdà and Doerr, 2008; Gabet and Sternberg, 2008; Onda et al., 2008; Woods and Balfour, 2008, 2010; Larsen et al., 2009; Zavala et al., 2009; Pereira et al., 2013b, 2013c). The spatial variability of the thickness of the ash layer may be affected by factors such as soil properties and ash texture. These factors depend on the temperature and severity of the fire, the moisture content of fuel, the amount and type of biomass and fuel distribution.

\subsubsection{Soil water repellency}

Water repellency is a property of some soils which reduces its affinity for water, reducing the rate of infiltration of water during periods of hours, days or weeks (Jordán et al., 2013). By reducing the rate of infiltration, increases runoff generation rate and volume of surface flow, which has other important consequences, as a significant increase in risk of erosion (Doerr et al., 2000; Shakesby and Doerr, 2006), irregular patterns of infiltration (Ritsema and Dekker, 1994; Leighton-Boyce et al., 2005) or a decrease in soil fertility by reducing the volume of soil available for roots (Blackwell, 2000). It is also have been observed increases in structural stability (Mataix-Solera and Doerr, 2004; Mataix-Solera et al., 2011) or carbon sequestration rate (Piccolo and Mbagwu, 1999). 
Forest fires are a major cause of water repellency and are widely considered a triggering factor in some cases. Several authors (DeBano and Krammes, 1966; Savage, 1974; DeBano, 1996) have described the process in which burning induces water repellency. According to these authors, the hydrophobic organic substances in litter and surface soil are volatilized during the fire. A small portion of this amount of material is displaced in depth, following the thermal gradient to condense back to a few inches below the surface. DeBano (1991) suggested that heating water repellent soils that contained more than 2-3\% organic matter always induce water repellency. Soil water repellency is induced or enhanced at temperatures of $200-250^{\circ} \mathrm{C}$. If temperature is greater than $300^{\circ} \mathrm{C}$, it can be destroyed. Robichaud and Hungerford (2000) and Zavala et al. (2010) found that by exposing different soil types in the laboratory to different heating temperature gradients impact water repellency, enhancing or reducing it depending on temperature reached. Other factors such as the amount and type of litter consumed and soil moisture immediately before burning can intensify or reduce the water repellency in the soils.

In general, soil is considered a poor conductor of heat. Consequently, thermal changes in deeper soil layers are usually unappreciable, despite flames occasionally exceed $1400^{\circ} \mathrm{C}$ (DeBano et al., 1998). Numerous studies show that temperatures between 500 and $800^{\circ} \mathrm{C}$ are reached during burning at the soil surface. In depth, however, the variability of records is very large, from an irrelevant variation at $5 \mathrm{~cm}$ deep to $100-300^{\circ} \mathrm{C}$. After studying the effects of temperature in a laboratory experiments DeBano and Krammes (1966) found that temperatures between 480 and $540^{\circ} \mathrm{C}$ during 25 -minutes periods may destroy water repellency at the topsoil, whereas it may be enhanced at temperatures around $200^{\circ} \mathrm{C}$ during 10 minutes. In laboratory experiments, several authors have found that temperatures between 250 and $350^{\circ} \mathrm{C}$ are sufficient to induce soil water repellency (DeBano et al., 1966; Robichaud and Hungerford, 2000; García-Corona et al., 2004; Zavala et al., 2009). DeBano and Krammes (1966) observed that, after 5 minutes at $60{ }^{\circ} \mathrm{C}$, soil showed extreme repellency. At $800^{\circ} \mathrm{C}$, water repellency begins to diminish after only 10 minutes and is completely destroyed after 20 minutes, while soil renders completely wettable after only 10 minutes at $900^{\circ} \mathrm{C}$ (DeBano and Krammes, 1966). Field studies have shown that rock fragments on the soil surface cause an heterogeneous pattern of temperature gradients, which contribute to enhance and/or destroy water repellency (Gordillo-Rivero et al., 2013).

Some authors have suggested that fire-induced water repellency is the result of chemical reactions that occur during burning, which intensifies the interaction between hydrophobic substances and soil particles (Savage et al., 1972), and makes them even more hydrophobic due to pyrolysis (Giovannini, 1994), rather than the volatilizationcondensation mechanisms. In addition, factors such as the accumulation of ash, volatilization of organic compounds during combustion and subsequent condensation around soil aggregates, can induce or increase hydrophobicity.

\subsubsection{Changes on soil texture, structure and porosity}

Partial or complete combustion of soil organic matter after moderate- or highseverity burning induce changes in soil aggregation (Mataix-Solera et al., 2011). 
Consequently, changes in related properties as porosity or water retention capacity may occur (Neary et al., 1999). High-intensity fires may cause thermal fusion of clay-size particles, increasing silt and sand percentages (Dyrness and Youngberg, 1957; Nishita and Haug, 1972; Ulery and Graham, 1993) due to thermal changes in aluminosilicates and iron oxides and hydroxides (Betremieux et al., 1960; Giovannini et al., 1990). Also, post-fire increased erosion rates may select coarser particles or aggregates and favor the loss of fine materials.

Major factors conditioning soil aggregation are the content and type of clay, cations, attractive and cohesion forces between the components of aggregates, microbial activity, Fe and Al oxides and organic matter (Mataix-Solera et al., 2011). After a wildfire, combustion of organic matter is the major cause of destruction of aggregates. If heavy rainfall (summer and autumn storms in Mediterranean climate) occurs before vegetation cover is reestablished, the impact of raindrops on bare soils may contribute to the development of surface crusts, reducing the infiltration rate, increasing runoff generation and velocity and favoring the loss of nutrients (Mataix-Solera et al., 2011).

There are certain factors that induce an increase of the structural stability after burning, according to Mataix-Solera et al. (2011). Firstly, the type of fire. In the case of crown fire, where fire does not directly affect soil, burning can result in an increment of soil organic matter content due to the incorporation of residues from semipyrolized vegetation. This hypothesis cannot explain an immediate increase, but it facilitates medium or long-term relatively high organic matter content in burned soils. Secondly, the mineralogy of the clay fraction, which can be modified by heating and forms more stable aggregates. Third, the combustion of organic matter, which destroys some soil aggregates. In this case, the most resistant aggregates are selected. Fourth, the presence of hydrophobic compounds may increase the stability of aggregates. In general, lowintensity fires do not induce important changes in soil aggregate stability, although in some cases, increased stability has been attributed to the development of water repellency after burning. Overall high severity fires cause major changes, but different trends are observed depending on the type of soil affected. If the temperature is high enough, there may be a stronger aggregation due to recrystallization of $\mathrm{Fe}$ and $\mathrm{Al}$ hydroxides. Although this increase is positive for soil protection against erosion, it means no benefit for soil-system functioning, as this increased stability is promoted by melting clays and similar causes, in the case of aggregates with a very small amount of organic matter. This deficit directly affects the regeneration of vegetation and indirectly the soil erosion of the burned area (Mataix-Solera et al., 2011).

\subsection{Effects on soil chemical properties}

\subsubsection{Soil acidity}

Soil acidity usually decreases after fire due to the destruction of organic acids and the contribution of carbonates, bases and oxides from ash (Kutiel et al., 1990; Ulery et al., 1995; Granged et al., 2011a, b). After high-intensity fire and reduction of soil organic matter by combustion, $\mathrm{pH}$ can increase significantly in 4 or 5 units (Ulery et 
al., 1995) mainly due to the loss of $\mathrm{OH}$ - groups from clay minerals, the formation of oxides (Giovannini et al., 1988, 1990), release of cations (Giardina et al., 2000; Arocena and Opium, 2003; Dikici and Yilmaz, 2006) or replacement of protons in the cation exchange complex (Arocena and Opio, 2003; Terefe et al., 2008). Some authors have observed decreased $\mathrm{pH}$ in soils exposed to high temperatures in the laboratory (Terefe et al., 2008), although soil heating experiments under laboratory conditions usually do not take into account the effect of ash.

In general, the increase of $\mathrm{pH}$ is ephemeral due to the formation of new humus and leaching of bases, although up to 50 years have been required to recover pre-fire soil pH in some cases (Viro, 1974; Khanna and Raison, 1986; Etiégni and Campbell, 1991). This period of time also depends on the soil buffer capacity. Sometimes, $\mathrm{pH}$ may recover very quickly after removal of ash by erosion processes (Zavala et al., 2009; Pereira et al., 2013).

\subsubsection{Cation exchange capacity}

Fire directly affects the cation exchange capacity (CEC) by combustion of soil organic matter and the transformation of clay minerals. Organic materials are altered at temperatures between 100 and $500^{\circ} \mathrm{C}$ (Knoepp et al., 2005), while minerals are altered at much higher temperatures. Consequently, CEC decreases after fire especially in the first few centimeters of soil depth. This decline can be more or less important depending on fire intensity, pre-fire organic matter content, soil mineralogy and the proportion of clay (Gil et al., 2010). Because of this, sandy soils show the greatest decrease in CEC after fire.

\subsubsection{Soluble salts content}

After exposure to moderate temperatures, soil electrical conductivity (EC) may increase significantly after the incorporation of soluble salts released by the combustion of organic matter (DeBano et al., 1977; Carballas, 1993; Kutiel and Inbar, 1993; Hernández et al., 1997). In the short term, cations contribute to an improvement of fertility in most cases, but the intake of soil nutrients may become limited by antagonistic interaction of minerals. In any case, changes in EC are usually ephemera, since salts are quickly leached or transported by runoff.

EC may also decrease in soils exposed to temperatures of about $500^{\circ} \mathrm{C}$, due to the destruction of clay minerals, the formation of oxides and the formation of coarse particles (Terefe et al., 2008).

\subsubsection{Nitrogen}

Nitrogen is one of the nutrients most affected by fire (Mataix-Solera and Guerrero, 2007). During combustion, most $\mathrm{N}$ is lost by volatilization at $200^{\circ} \mathrm{C}$ (Chandler et al., 1983; Prichett and Fisher, 1987; Fisher and Binkley, 2000; Turner et al., 2007). However, some authors have shown increases by the addition of partially pyrolyzed materials (Giovannini et al., 1988; Prieto-Fernández et al., 1993; Grogan et al., 2000). Volatilization of $\mathrm{N}$ during combustion is directly related to the temperatures reached in 
soil and the amount of organic matter consumed, but nitrification conditions usually are improved after burning (Mataix-Solera and Guerrero, 2007). Inorganic N concentrations tend to increase in burned areas more than in unburned control areas in the first years after fire (Smithwick et al., 2005; Turner et al., 2007; Boerner et al., 2009). Fire-induced changes in soil inorganic $\mathrm{N}$ content can be attributed to a combination of direct and indirect effects of fire, $\mathrm{N}$ release from dead roots and compounds where it was previously immobilized (Smithwick et al., 2005; Rivas et al., 2012). Nitrification is improved especially in burned acid soils, since decreased acidity enhances microbial activity and induces the germination of nitrogen-fixing legumes, such as Ulex parviflorus (Neary et al., 1999; Pastor-López and Martin-Martin, 1995; Raison et al., 2009), so that N levels are restored quickly (Kutiel and Naveh, 1987; Gimeno-García et al., 2000; Giovannini et al., 1990). Death of burned trees causes the loss of mycorrhizal associations and the uptake of nutrients decreases, increasing soil N content (Smithwick et al., 2005). Active resprouting plants prevent the alteration of the $\mathrm{N}$ cycle in soil, but $\mathrm{N}$ may be leached if vegetation is severely affected (Rivas et al., 2012). Although different impacts of fire on $\mathrm{N}$ availability have been observed by scientists, prediction is limited by a low understanding of the post-fire processes (Smithwick et al., 2005).

\subsubsection{Organic carbon}

Combustion causes a decrease in soil organic $\mathrm{C}$ content, but fire impacts may be much more complex depending on fire intensity and soil processes. After low-intensity fires, organic $\mathrm{C}$ content may increase from partially pyrolyzed plant residues. In contrast, medium- or high-intensity fire causes a decrease in soil organic C content (MataixSolera et al., 2002). According to Knoepp et al. (2005), more than $99 \%$ organic matter content may be destroyed by heating soil at $450{ }^{\circ} \mathrm{C}$ during two hours or at $500^{\circ} \mathrm{C}$ during 30 minutes. However, the loss of organic matter can be balanced by contributions from partially burned residues and charred leaves falling in the hours or days after fire (Gimeno-García et al., 2000; Terefe et al., 2008; Granged et al., 2011a, b).

Medium- or low-intensity fires may induce structural changes in aliphatic compounds, while humic acids may remain unchanged (Giovannini, 1994; Pardini et al., 2004; Badía et al., 2014). At higher temperatures, soil organic matter suffers modifications; the degree of stability and condensation of humic fractions induce a greater resistance to microbial degradation (Bodí et al., 2012a).

Organic matter concentrates on the surface of mineral soil, where it is particularly vulnerable to erosion when the vegetation cover and litter are removed by burning. The $\mathrm{C} / \mathrm{N}$ ratio is altered, increasing with temperature. Fire-affected soils show low free organic matter content, low polymerization of fulvic acids and increased content of humic acids and proportion of insoluble humins. However, these apparently beneficial changes do not last long and, if fire frequency increases, soil may become an inert medium, as carbonized plant residues (black carbon) are very difficult to transform (Knoepp et al., 2005; González-Vila et al., 2009). Black carbon is produced in large amounts and accumulated on the soil surface, where it may constitute $30-40 \%$ of soil $\mathrm{C}$ in fire-prone ecosystems. This long-term $\mathrm{C}$ sequestration is a significant part of the global C cyle (Forbes et al., 2006; Mataix-Solera and Guerrero, 2007; Bodí et al., 2012a). 


\section{Conclusions and future insights}

Wildfires are a natural ecological factor in Mediterranean ecosystems and have contributed to model the landscape that we know, together with its use as a tool for land use management for millennia. Scientific research over the last 20 years has confirmed that fire is necessary for proper functioning of the ecosystem in the Mediterranean forests.

Plant communities and soils from Mediterranean ecosystems have been selected and shaped by fire, and show a great capacity to regenerate after a burning. But it must be kept in mind that Mediterranean systems may suffer great impacts after man-induced changes and disturbance of the natural fire regime. Although fire should be considered a natural component of ecosystems, socio-economic changes in recent decades have contributed to an increment in forest fires, altering fire regimes and promoting the emergence of serious effects on soil, water and vegetation. This new situation requires an investment, not only in the prevention and suppression of forest fires, but also in research. In fact, in the last two decades, the scientific community has leaded research efforts on the effects of fire on physical and chemical soil properties in the short-, medium- and long-term. Due to the damage caused by forest fires in our ecosystems, it is necessary to know what are the changes that wildfires induce in soils, the causes and consequences of these alterations in soil functioning, and the natural ability of soils to recover. Future research should aim to investigate the degree of protection of soils after fire, the importance and evolution of impacts in the long-term and at basin or regional scales, and the main factors influencing this evolution.

There are also unanswered questions regarding the dynamics of physical properties of fire-affected soils. For example, the implications in terms of soil fertility and hydrology of increased aggregate stability due to thermal fusion clay, or how many time the soil system needs to form aggregates similar to those of the pre-fire situation. This topic should also take into account the evolving microbiology and microfauna of the area affected and the impact on soil structure.

Currently there is a great understanding of the impacts of fire on physical and chemical properties of the soil. However, very few studies have addressed the study of these impacts more comprehensively. An interdisciplinary and holistic approach is needed to study the impact of fire on soils that facilitates the understanding of the complexity of interactions between the physical, chemical and biological properties of the soil, as well as hydrological and geomorphological consequences at different scales. This will contribute to develop adequate strategies for the restoration of fire-affected areas.

\section{Acknowledgments}

Authors acknowledge the Spanish Ministry of Economy and Competitiveness for supporting the research projects HYDFIRE (Repelencia al agua de suelos mediterráneos afectados por el fuego. Factores implicados, evolución temporal e implicaciones edafológicas e hidrológicas, CGL2010-21670-C02-01) and GEOFIRE (Alteraciones geoquímicas en suelos afectados por el fuego, CGL2012-38655-C04-01). Authors are also 
grateful to the Spanish Network Effects of Wildfires on Soils (FUEGORED, http://grupo. us.es/fuegored).

\section{References}

Agee, J.K. 1993. Fire Ecology of Pacific Northwest Forests. Island Press, Washington, DC, Covelo, CA.

Albini, F.A. 1976. Estimating wildfire behavior and effects. General Technical Report INT-30, United States Department of Agriculture, Forest Service, Intermountain Forest and Range Experiment Station, Ogden, UT.

Alexander, M.E. 1982. Calculating and interpreting forest fire intensities. Canadian Journal of Botany 60, 349-357.

Arocena, J.M., Opio, C. 2006. Prescribed fire-induced changes in properties of sub-boreal forest soils. Geoderma 113, 1-16.

Badía-Villas, D., González-Pérez, J.A., Aznar, J.M., Arjona-Gracia, B., Martí-Dalmau, C. 2014. Changes in water repellency, aggregation and organic matter of a mollic horizon burned in laboratory: Soil depth affected by fire. Geoderma 213, 400-407.

Bárcenas-Moreno, G., Baath, E. 2009. Bacterial and fungal growth in soil heated at different temperatures to simulate a range of fire intensities. Soil Biology and Biochemistry 41, 25172526.

Bárcenas-Moreno, G., García-Orenes, F., Mataix-Solera, J., Mataix-Beneyto, J., Baath, E. 2011. Soil microbial recolonisation after a fire in a Mediterranean forest. Biology and Fertility of Soils 47, 261-272.

Bengtsson, J. 2002. Disturbance and resilience in soil animal communities. European Journal of Soil Biology 38, 119-125.

Betremieux, R., Le Borgne, E., Monnier, G. 1960. Evolution de certaines proriétés du sol sous l'influence du chauffage. Comptes Rendus de l'Academie des Sciences de Paris 251, 2753 2755.

Bezkorovainaya, I.N., Krasnoshchekova, E.N., Ivanova, G.A. 2007. Transformation of soil invertebrate complex after surface fires of different intensity. Biology Bulletin 34, 517-522.

Blackwell, P.S. 2000. Management of water repellency in Australia, and risks associated with preferential flow, pesticide concentration and leaching. Journal of Hydrology 231-232, 384395.

Bodí, M.B., Cerdà, A., Mataix-Solera, J., Doerr, S.H. 2012a. Efectos de los incendios forestales en la vegetación y el suelo en la cuenca mediterránea: revisión bibliográfica. Boletín de la Asociación de Geógrafos Españoles 58, 33-55.

Bodí M.B., Doerr S.H., Cerdà A., Mataix-Solera J. 2012b. Hydrological effects of a layer of vegetation ash on underlying wettable and water repellent soil. Geoderma 191, 14-23.

Boerner, R.E.J., Huang, J.J., Hart, S.C. 2009. Impacts of fire and fire surrogate treatments on forest soil properties: a meta-analytical approach. Ecological Applications 19, 338-358.

Bond, W.J., Keeley, J.E. 2005. Fire as a global "herbivore": the ecology and evolution of flamable ecosystems. TRENDS in Ecology and Evolution 20, 387-394.

Bond, W.J., Van Wilgen, B.W. 1996. Fire and plants. Population and community biology. Chapman and Hall, London.

Cairney, J.W.G., Bastias, B.A. 2007. Influences of fire on forest soil fungal communities. Canadian Journal of Forest Research 37, 207-215.

Campbell, R.E., Baker, M.B., Folliott, P.F. 1977. Wildfire effects on a ponderosa pine ecosystem: an Arizona case study. USDA Forest Service Papers, RM-191, Rocky Mountain Forest and 
Range Experimental Station, United States Department of Agriculture, Forest Service, Fort Collins, CO.

Carballas, T. 1993. Organic matter, nitrogen, phosphorus and microbial population evolution in forest humiferous acid soils after wildfires. In Fire in Mediterranean ecosystems, L. Trabaud, R. Prodon, (eds.), Ecosystems Research Series EEC, report n 5, Brussels, pp. 379385 .

Cerdà, A. 1998. Postfire dynamics of erosional processes under mediterranean climatic conditions. Zeitschrift für Geomorphologie 42, 373-398.

Cerdà, A., Bodí, M.B. 2007. Erosión hídrica en suelos afectados por incendios forestales. In Incendios forestales, suelos y erosión hídrica, J. Mataix-Solera (ed.), Caja de Ahorros del Mediterráneo CEMACAM, Alcoi, pp. 71-118.

Cerdà, A., Doerr, S.H. 2008. The effect of ash and needle cover on surface runoff and erosion in the immediate post-fire period. Catena 74, 256-263.

Certini, G. 2005. Effects of fire on properties of forest soils: a review. Oecologia 143, 1-10.

Chandler, C., Cheney, P., Thomas, P., Trabaud, L., Williams, D. 1983. Fire in forestry. Vol. 1. Forest fire behaviour and effects. John Wiley \& Sons, New York, NY.

Crosti, R., Ladd, P.G., Dixon, K.W., Piotto, B. 2006. Post-fire germination: the effect of smoke on seeds of selected species from the central Mediterranean basin. Forest Ecology and Management 221, 306-312.

De la Rosa, J.M., Knicker, H., López-Capel, E., Manning, D.A.C., González-Pérez, J.A., GonzálezVila, F.J. 2008. Direct detection of black carbon in soils by Py-GC/MS, Carbon-13 NMR spectroscopy and thermogravimetric techniques. Soil Science Society of America Journal 72, 258-267.

De Luis, M., González-Hidalgo, J.C., Raventós, J. 2003. Effects of fire and torrential rainfall on erosion in a Mediterranean gorse community. Land Degradation and Development 14, 203-213.

DeBano, L.F., Krammes, J.S. 1966. Water repellent soils and their relation to wildfire temperatures. International Association of Scientific Hydrology Bulletin 11, 14-19.

DeBano, L.F. 1991. Effects of Fire on Soil Properties. General Technical Report, INT-280, USDA Forest Service, Berkeley, CA.

DeBano, L.F. 1996. Formation of non-wettable soils involves heat transfer mechanism. USDA Forest Service Research Note PSW-132, Berkeley, CA.

DeBano, L.F., Dunn, P.H., Conrad, C.E. 1977. Fire's effect on physical and chemical properties of chaparral soils. I. Soil nitrogen. Soil Science Society of America Journal 43, 504-509.

DeBano, L.F., Neary, D.G., Folliott, P.F. 1998. Fire's effects on ecosystems. John Wiley \& Sons, New York, NY.

Demeyer, A., Vuondi Nkana, J.C., Verloo, M.G. 2001. Characteristics of wood ash and influence in soil properties and nutrient uptake: an overview. Bioresource Technology 77, 253-266.

Dikici, H., Yilmaz, C.H. 2006. Peat fire effects on some properties of an artificially drained peatland. Journal of Environmental Quality 35, 866-870.

Doerr, S.H., Shakesby, S.H., Walsh, R.P.D. 2000. Soil water repellency: its causes, characteristics and hydro-geomorphological significance. Earth-Science Reviews 51, 33-65.

Doerr, S.H., Shakesby, R.A., Dekker, L.W., Ritsema, C.J. 2006. Occurrence prediction and hydrological effects of water repellency amongst major soil and land-use types in a humid temperate climate. European Journal of Soil Science 57, 741-754.

Dunn, P.H., Barro, S.C., Poth, M. 1985. Soil moisture affects survival of microorganisms in heated Chaparral soil. Soil Biology and Biochemistry 17, 143-148.

Dyrness, C.T., Youngberg, C.T. 1957. The effects of logging and slash burning on soil structure. Soil Science Society of America Proceedings 21, 444-447. 
Eckmeier, E., Egli, M., Hagedorn, F., Schmidt, M.W.I. 2010. Preservation of fire-derived carbon compunds and sorptive stabilization promote the accumulation of organic matter in black soils of the Southern Alps. Geoderma 159, 147-155.

Eckmeier, E., Mavris, C., Krebs, R., Pichler, B., Egli, M. 2013. Black carbon contributes to organic matter in young soils in the Morterasch proglacial area (Switzerland). Biogeosciences 10, 1265-1274.

Eiten, G. 1992. Natural Brazilian vegetation types and their causes. Anais da Academia Brasileira de Ciencias 64, 35-65.

Etiégni, L., Campbell, A.G. 1991. Physical and Chemical characteristics of wood ash. Bioresource Technology 37, 173-178.

Fernández, C., Vega, J.A., Gras, J.M., Fonturbel, T., Cuiñas, P., Dambrine, E., Alonso, M. 2004. Soil erosion after Eucalyptus globulus clearcutting: differences between logging slash disposal treatments. Forest Ecology and Management 195, 85-95.

Ferran, A., Vallejo, R. 1992. Litter dynamics in post-fire successional forests of Quercus ilex. Vegetatio 99-100, 239-246.

Ferran, A., Vallejo, R. 1998. Long-term plant regeneration after wildfires in Mediterranean ecosystems of NE Spain. In Fire management and landscape ecology, L.V. Trabaud (ed.), Fairfield, Washington, DC, pp. 155-166.

Fisher, R.F., Binkley, D. 2000. Ecology and management of forest soils. 3rd ed. John Wiley \& Sons, New York, NY.

Flannigam M.D., Stocks, B.J., Wotton, B.M. 2000. Climate change and forest fires. The Science of the Total Environment 262, 221-229.

Forbes, M.S., Raison, R.J., Skjemstad, J.O. 2006. Formation, transformation and transport of black carbon (charcoal) in terrestrial and aquatic ecosystems. Science of the Total Environment 370, 190-206.

Frandsen, W.H., Ryan, K.C. 1986. Soil moisture reduces belowground heat flux and soil temperature under a burning fuel pile. Canadian Journal of Forest Research 16, 244-248.

Gabet, E.J., Sternberg, P. 2008. The effects of vegetative ash on infiltration capacity sediment transport and generation of progressively bulked debris flows. Geomorphology 101, 666673.

García-Corona, R., Benito, E., De Blas, E., Varela, M.E. 2004. Effects of heating on some soil physical properties related to its hydrological behaviour in two north-western Spanish soils. International Journal of Wildland Fire 13, 195-199.

Giardina, C.P., Sanford, R.L., Dockersmith, I.C. 2000. Changes in soil phosphorus and nitrogen during slash-andburn clearing of a dry tropical forest. Soil Science Society of America Journal 64, 339-405.

Gil, J., Zavala, L.M., Bellinfante, N., Jordán, A. 2010. Acidez y capacidad de intercambio catiónico en los suelos afectados por incendios. Métodos de determinación e interpretación de resultados. In Actualización en métodos y técnicas de estudio de los suelos afectados por incendios forestales, A. Cerdà, A. Jordán (eds.), Cátedra de Divulgació de la Ciència, Valencia, pp. 315-331.

Gimeno-García, E., Andreu, V., Rubio, J.L. 2000. Changes in organic matter, nitrogen, phosphorus and cations as a result of fire and water erosion in a Mediterranean landscape. European Journal of Soil Science 51, 201-210.

Giovannini, G. 1994. The effect of fire on soil quality. In Soil erosion as a consequence of forest fires, M. Sala, J.L. Rubio (eds.), Geoforma Ediciones, Logroño, pp. 15-27.

Giovannini, G., Lucchesi, S., Giachetti, M. 1988. Effect of heating on some physical and chemical parameters related to soil aggregation and erodibility. Soil Science 146, 255-262. 
Giovannini, G., Lucchesi, S., Giachetti, M. 1990. Effect of heating on some chemical parameters related to soil fertility and plant growth. Soil Science 149, 344-350.

Gongalsky, K.B., Persson, T. 2013. Recovery of soil macrofauna after wildfires in boreal forests. Soil Biology and Biochemistry 57, 182-191.

Gongalsky, K.B., Midtgaard, F., Overgaard, H.J. 2006. Effects of prescribed forest burning on carabid beetles (Coleoptera: Carabidae): a case study in south-eastern Norway. Entomologica Fennica 17, 325-333.

Gongalsky, K.B., Wikars, L.O., Persson, T. 2008. Ground beetle (Coleoptera: Carabidae) responses to a forest wildfire in northern Europe. Russian Entomological Journal 17, 273 282.

González-Vila, F.J., Almendros, G., González-Pérez, A., Knicker, H., González-Vázquez, R., Hernández, Z., Piedra-Buena, A., De La Rosa, J. M. 2009. Transformaciones de la materia orgánica del suelo por incendios naturales y calentamientos controlados en condiciones de laboratorio. In Efectos de los incendios forestales sobre los suelos en España. El estado de la cuestión visto por los científicos españoles, A. Cerdà, J. Mataix-Solera (eds.), Cátedra de Divulgación de la Ciencia, Universitat de València, Valencia, pp. 219-267.

Gordillo-Rivero, A.J., García-Moreno, J., Jordán, A., Zavala, L.M., Granja-Martins, F.M. 2013. Fire severity and surface rock fragments cause patchy distribution of soil water repellency and infiltration rates after burning. Hydrological Processes. DOI: 10.1002/hyp.10072.

Granged, A.J.P., Jordán, A., Zavala, L.M., Muñoz-Rojas, M., Mataix-Solera, J. 2011a. Short-term effects of experimental fire for a soil under eucalypus forest (SE Australia). Geoderma 167$168,125-134$.

Granged, A.J.P., Zavala, L.M., Jordán, A., Bárcenas-Moreno, G. 2011b. Post-fire evolution of soil properties and vegetation cover in a Mediterranean heathland after experimental burning: a 3-year study. Geoderma 164, 85-94.

Grogan, P., Bruns T.D., Chapin, F.S. 2000. Fire effects on ecosystem nitrogen cycling in a Californian bishop pine forest. Oecologia 122, 537-544.

Guerrero, C., Gómez, I., Mataix Solera, J., Moral, R., Mataix Beneyto, J., Hernández, M.T. 2000. Effect of solid waste compost on microbiological and physical properties of a burnt forest soil in field experiments. Biology and Fertility of Soils 32, 410-414.

Guerrero, C., Mataix-Solera, J., Gómez, I., García-Orenes, F., Jordán, M.M. 2005. Microbial recolonization and chemical changes in soil heated at different temperatures. International Journal of Wildland Fire 14, 385-400.

Hajdas, I., Schlumpf, N., Minikus-Stary, N., Hagedorn, F., Eckmeier, E., Schoch, W., Burga, C., Bonani, G., Schmidt, M.W.I., Cherubini, P. 2007. Radiocarbon ages of soil charcoals from the southern Alps, Ticino, Switzerland. Nuclear Instruments and Methods in Physics Research B 259, 398-402.

Hartford, R.A., Frandsen, W.H. 1992. When it's hot, it's hot ... or maybe it's not (surface flaming may not portend extensive soil heating). International Journal of Wildland Fire 2, 139-144.

Hernández, T., García, C., Reinhardt, I. 1997. Short-term effect of wildfire on the chemical, biochemical and microbiological properties of Mediterranean pine forest soils. Biology and Fertility of Soils 25, 109-116.

Inbar, M., Tamir, M., Wittenberg, L. 1998. Runoff and erosion processes after a forest fire in Mount Carmel, a Mediterranean area. Geomorphology 24, 17-33.

Jordán, A., Zavala, L.M., Mataix-Solera, J., Doerr, S.H. 2013. Soil water repellency: Origin, assessment and geomorphological consequences. Catena 108, 1-5.

Keeley, J.E. 2009. Fire intensity, fire severity and burn severity: a brief review and suggested usage. International Journal of Wildland Fire 18, 116-126. 
Ketterings, Q.M., Bigham, J.M., Laperche, V. 2000. Changes in soil mineralogy and texture caused by slash-and-burn fires in Sumatra, Indonesia. Soil Science Society of American Journal 64, 1108-1117.

Khanna, P.K., Raison, R.J. 1986. Effect of fire intensity on solution chemistry of surface soil under a Eucalyptus pauciflora forest. Australian Journal of Soil Research 24, 423-434.

Khanna, P.K., Raison, R.J. Falkiner, R.A., 1994, Chemical properties of ash derived from Eucalyptus litter and its effects on forest soils. Forest Ecology and Management 66, 107125.

Knoepp, J.D., DeBano, L.F., Neary, D.G. 2005. Soil Chemistry. In Wildland fire in ecosystems: effects of fire on soils and water, D.G. Neary, K.C. Ryan, L.F. DeBano (eds.), General Techical Report RMRS-GTR-42-vol.4. United States Department of Agriculture, Forest Service and Rocky Mountain Research Station, Ogden, UT, pp. 53-71.

Kutiel, P. 2006. Fire and ecosystem heterogeneity: A Mediterranean case of study. Earth Surface Processes and Landforms 19, 187-194.

Kutiel, P., Inbar, M. 1993. Fire impacts on soil nutrients and soil erosion in a mediterranean pine forest plantation. Catena 20, 129-139.

Kutiel, P., Naveh, Z. 1987. Soil properties beneath Pinus halepensis and Quercus calliprinos trees on burned and unburned mixed forest on Mt. Carmel, Israel. Forest Ecology and Management 20, 11-24.

Kutiel, P., Naveh, Z., Kutiel, H. 1990. The effect of a wildfire on soil nutrients and vegetation in an Aleppo pine forest on Mount Carmel, Israel. In Fire and ecosystems dynamics. Mediterranean and northern dynamics, J.C. Goldamer, M.J. Jenkins (eds.), SPB Academy Publishing, The Hague.

Larsen, I., Macdonald, L.H., Brown, E., Rough, D., Welsh, M.J., Pietraszek, J.H., Libohava, Z., Benavides-Solorio, J.D., Schaffrath, K. 2009. Causes of post-fire runoff and erosion: water repellency, cover, or soil sealing? Soil Science Society of America Journal 73, 1393-1407.

Leighton-Boyce, G., Doerr, S.H., Shakesby, R.A., Walsh, R.P.D. 2005. Quantifying the impact of soil water repellency on overland flow generation and erosion: a new approach using rainfall simulation and wetting agent on in situ soil. Hydrological Processes 21, 2337-2435.

Lloret, F., Zedler, P.H. 2009. The effect of forest fire on vegetation. In Fire effects on soils and restoration strategies, A. Cerdà, P.R. Robichaud (eds.), Science Publishers, Enfield, pp. 257295.

Mallik, A.U., Gimingham, C.H., Rahman, A.A. 1984. Ecological effects of heather burning. I. Water infiltration, moisture retention and porosity surface soil. Journal of Ecology 72, 787776.

Malmström, A., Persson, T., Ahlström, K., Gongalsky, K.B., Bengtsson, J. 2009. Dynamic of soil meso-and macrofauna during a 5 -year period after clear-cut burning in a boreal forest. Applied Soil Ecology 43, 61-74.

Margaris, N.S., Koutsidou, E., Giourga, C. 2000. Changes in traditional Mediterranean land-use systems. In Mediterranean desertification and land use, C.J. Brandt, J.B. Thornes (eds.), Chichester, Wiley, pp. 29-42.

Mataix-Solera, J., Doerr, S.H. 2004. Hydrophobicity and aggregate stability in calcareous topsoils from fire-affected pine forest in southeastern Spain. Geoderma 118, 77-88.

Mataix-Solera, J., Guerrero, C. 2007. Efectos de los incendios forestales sobre las propiedades edáficas. In Incendios forestales, suelos y erosión hídrica, J. Mataix-Solera (ed.), Caja de Ahorros del Mediterráneo CEMACAM, Alcoi, pp. 5-40.

Mataix-Solera, J, Gómez, I., Navarro-Pedreño, J., Guerrero, C., Moral, R. 2002. Soil organic matter and aggregates affected by wildfire in a Pinus halepensis forest in Mediterranean environment. International Journal of Wildland Fire 11, 107-111. 
Mataix-Solera, J., Cerdà, A., Arcenegui, V., Jordán, A., Zavala, L.M. 2011. Fire effects on soil aggregation: A review. Earth-Science Reviews 109, 44-60.

Metz, L., Dindal, D. 1980. Effects of fire on soil fauna in North America. In Soil biology as related to land use practices, EPA-560/13-80-038, D.L. Dindal (ed.), Office of Pesticide and Toxic Substances, EPA, Washington, DC, pp. 450-459.

Misra, M.K., Ragland, K.W., Baker, A.J. 1993. Wood ash composition as function of furnace temperature. Biomass and Bioenergy 4, 291-303.

Moreno, J.M., Oechel, W.C. 1995. The role of fire in Mediterranean type ecosystems. Springer, New York, NY.

Moreno, J.M., Vázquez, A., Vélez, R. 1998. Recent history of forest fires in Spain. In Large forest fires, J.M. Moreno (ed.), Backhuys Publishers, Leiden, pp. 159-186.

Moretti, M., Duelli, P., Obrist, M. 2006. Biodiversity and resilience of arthropod communities after fire disturbance in temperate forests. Oecologia 149, 312-327.

Neary, D.G., Klopatek, C.C., DeBano, L.F., Ffolliott, P.F. 1999. Fire effects on belowground sustainability: a review and synthesis. Forest Ecology and Management 122, 51-71.

Neary, D.G., Ryan, K.C., DeBano, L.F. 2005. Wildland fire in ecosystems: effects of fire on soils and water. General Techical Report RMRS-GTR-42-vol.4. USDA, Forest Service, Rocky Mountain Research Station, Ogden, UT.

Nishita, H., Haug, R.M. 1972. Some physical and chemical characteristics of heated soils. Soil Science 113, 422-430.

Noble, I.R., Slatyer, R.I. 1980. The use of vital attributes to predict successional changes in plant communities subject to recurrent disturbances. Vegetatio 43, 5-21.

Onda, Y., Dietrich W.E., Booker, F. 2008. Evolution of overland flow after severe forest fire, Point Reyes, California. Catena 72, 13-20.

Packham, D., Pompe, A. 1971. The radiation temperatures of forest fires. Australian Forest Research 5, 1-8.

Paine, R.T., Tegner, M.J., Johnson, E.A. 1998. Compounded perturbations yield ecological surprises. Ecosystems 1, 535-545.

Pardini, G., Gispert, M., Dunjó, G. 2004. Relative influence of wildfire on soil properties and erosion processes in different Mediterranean environments in NE Spain. Science of the Total Environment 328, 237-246.

Pastor-López, A., Martin-Martin, J. 1995. Potential nitrogen losses due to fire from Pinus halepensis stands in the Alicante Province (Southeastern Spain): Mineralomass variability. In The Biswell Symposium: Fire issues and solutions in urban interface and wildland ecosystems. Pacific Southwest Research Station, USDA Forest Service, Albany, CA.

Paula, S., Cervello, C.P., Pausas, J.G. 2006. Fire as a germination cue: A review for the Mediterranean basin. Forest Ecology and Management 234S, S151-S179.

Pausas, J.G. 2004. Changes in fire and climate in the eastern Iberian Peninsula (Mediterranean basin). Climatic Change 63, 337-350.

Pausas, J.G., Keeley, J.E. 2009. A burning story: the role of fire in the history of life. BioScience 59, 593-601.

Pausas, J.G., Verdú, M. 2005. Plant persistence traits in fire-prone ecosystems of the Mediterranean Basin: a phylogenetic approach. Oikos 109, 196-202.

Pausas, J.G., Llovet, J., Rodrigo, A., Vallejo, R. 2008. Are wildfires a disaster in the Mediterranean basin?-A review. International Journal of Wildland Fire 17, 173-723.

Pereira, P., Úbeda, X., Martin, D. 2009. Application of a cluster analysis, on the relationship between fire temperature and solutes release in some Mediterranean species. Silva Lusitana $17,39-50$. 
Pereira, P., Bodí, M., Úbeda, X., Cerdà, A., Mataix-Solera, J., Balfour, V., Woods, S. 2010. Las cenizas y el ecosistema suelo. In Actualización en métodos y técnicas de estudio de los suelos afectados por incendios forestales, A. Cerdà, A. Jordán (eds.), Cátedra de Divulgació de la Ciència, Valencia, pp. 345-398.

Pereira, P., Cerdà, A., Bolutiene, V., Úbeda, X., Pranskevicius, M., Jordán, A., Zavala, L.M., Mataix-Solera, J. 2013a. Spatio-temporal effects of low severity grassland fire on soil colour. Geophysical Research Abstracts 15, EGU2013-10641.

Pereira, P., Úbeda, X., Cerdà, A., Mataix-Solera, J., Martin, D., Jordán A., Burguet, M. 2013b. Spatial models for monitoring the spatio-temporal evolution of ashes after fire - a case study of a burnt grassland in Lithuania. Solid Earth 4, 153-165.

Pereira, P., Cerdà, A., Úbeda, X., Mataix-Solera, J., Arcenegui, V., Zavala, L.M. 2013c. Modelling the impacts of wildfire on ash thickness in a short-term period. Land Degradation and Development. DOI: 10.1002/ldr.2195.

Pérez-Cabello, F., Ibarra, P., Echeverría, M.T., de la Riva, J. 2010. Post-fire land degradation of Pinus sylvestris L. woodlands after 14 years. Land Degradation \& Development 21, 145 160 ,

Pérez-Cabello, F., Cerdà. A., de la Riva, J., Echeverría, M.T., García-Martín, A., Ibarra, P., Lasanta, T., Montorio, R., Palacios, V. 2012. Micro-scale post-fire surface cover changes monitored using high spatial resolution photography in a semiarid environment: A useful tool in the study of post-fire soil erosion processes. Journal of Arid Environments 76, 88-96.

Piccolo, A., Mbagwu, J.S.C. 1999. Role of hydrophobic components of soil organic matter in soil aggregate stability. Soil Science Society of America Journal 63, 1801-1810.

Pietikäinen, J., Fritze, H. 1995. Clear-cutting and prescribed burning in coniferous forest: comparison of effects on soil fungal and total microbial biomass, respiration activity and nitrification. Soil Biology and Biochemistry 27, 101-109.

Ponder Jr., F., Tadros, M., Loewenstein, E.F. 2009. Microbial properties and litter and soil nutrients after two prescribed fires in developing savannas in an upland Missouri Ozark Forest. Forest Ecology and Management 257, 755-763.

Prieto-Fernández, A., Villar, M.C., Carballas, M., Carballas, T. 1993. Short-term effects of a wildfire on the nitrogen status and its mineralization kinetics in an Atlantic forest soil. Soil Biology and Biochemistry 25, 1657-1664.

Pritchett, W.L., Fisher, R.F. 1987. Properties and management of forest soils. Second Edition. John Wiley \& Sons, New York, NY.

Pyne, S.J. 2001. Fire: A brief history. University of Washington Press, Seattle, WA.

Raison, R.J., Khanna, P.K., Jacobsen, K.L.S., Romanya, J., Serrasolses, I. 2009. Effect of fire on forest nutrient cycles. In Fire effects on soils and restoration strategies, A. Cerdà, P.R. Robichaud (eds.), Science Publishers, Enfield, pp. 225-256.

Ritsema, C.J., Dekker, L.W. 1994. How water moves in a water repellent sandy soil. 2. Dynamics of fingered flow. Water Resources Research 30, 2519-2531.

Rivas, Y., Huygens, D., Knicker, H., Godoy, R., Matus, F., Boeckx, P. 2012. Soil nitrogen dynamics three years after a severe Araucaria-Nothofagus forest fire. Austral Ecology 37, 153-163.

Robichaud, P.R., Hungerford, R.D. 2000. Water repellency by laboratory burning of four northern Rocky Mountain forest soils. Journal of Hydrology 231-232, 207-219.

Robichaud, P.R., Beyers, J.L., Neary, D.G. 2000. Evaluating the effectiveness of postfire rehabilitation treatments. General Technical Report, RMRS-GTR-63, USDA Forest Service, Rocky Mountain Research Station, Ogden, UT.

Robinson, J.M. 1991. Fire from space: Global fire evaluation using infrared remote sensing. International Journal of Remote Sensing 12, 3-24. 
Ruiz Del Castillo, J. 2000. Efectos del fuego en los ecosistemas forestales. In La defensa contra incendios forestales. Fundamentos y experiencias, R. Vélez (coord.), McGraw Hill, Madrid.

Ryan, K.C. 2002. Dynamic interactions between forest structure and fire behavior in boreal ecosystems. Silva Fennica 36, 13-39.

Savage, S.M. 1974. Mechanism of fire-induced water repellency in soil. Soil Science Society America Proceedings 38, 652-657.

Savage, S.M., Osborn, J., Letey, J., Heaton, C. 1972. Substances contributing to fire-induced water repellency in soils. Soil Science Society America Proceedings 36, 674-678.

Schmidt, M.W.I., Skjemstad, J.O., Gehrt, E., Kögel-Knabner, I. 1999. Charred organic carbon in German chernozemic soils. European Journal of Soil Science 50, 351-365.

Scott, A.C. 2000. The Pre-Quaternary history of fire. Palaeo 164, 281-329.

Scott, A.C. 2009. Forest fire in the fossil record. In Fire effects on soils and restoration strategies, A. Cerdà, P.R. Robichaud (eds.), Science Publishers, Enfield, pp. 1-37.

Shakesby R.A. 2011. Post-wildfire soil erosion in the Mediterranean: Review and future research directions. Earth-Science Reviews 105, 71-100.

Shakesby, R.A., Doerr, S.H. 2006. Wildfire as hydrological and geomorphological agent. EarthScience Reviews 74, 269-307.

Simard, A.J. 1991. Fire severity, changing scales, and how things hang together. International Journal of Wildland Fire 1, 23-34.

Smithwick, E.A.H., Turner, M.G., Mack, M.C., Chapin, F.S. 2005. Postfire soil N cycling in northern conifer forests affected by severe, stand-replacing wildfires. Ecosystems 8, 163-181.

Terefe, W.T., Mariscal, S.I., Gómez, M.V., Espejo, S.R. 2005. Influence of heating on various properties of six Mediterraean soils. A laboratory study. Geoderma 143, 273-380.

Terefe, W.T., Mariscal, S.I., Gómez, M.V., Espejo, S.R. 2008. Relationship between soil color and temperature in the surface horizon of Mediterranean soils: a laboratory study. Soil Science 170, 495-503.

Trabaud, L. 2000. Post-fire regeneration of Pinus halepensis forest in the west Mediterranean. In Ecology, biogeography and management of Pinus halepensis and P. brutia forest ecosystems in the Mediterranean basin, G. Ne'eman, L. Trabaud (eds.), Backhuys Publishers, Leiden, pp. 257-268.

Turner, M.G., Smithwick, E.A.H., Metzger, K.L, Tinker, D.B., Romme, W.H. 2007. Inorganic nitrogen availability after severe stand-replacing fire in the Greater Yellowstone ecosystem. Proceedings of the National Academy of Sciences 104, 4782-4789.

Úbeda, X., Pereira, P., Outeiro, L., Martin, D. 2009. Effects of fire temperature on the physical and chemical characteristics of the ash from two plots of cork oak (Quercus suber). Land Degradation and Development 20, 589-609.

Ulery A.L., Graham, R.C. 1993. Forest fire effects on soil color and texture. Soil Science Society of America Journal 57, 135-140.

Ulery, A., Graham, R.C., Amrhein, C. 1993. Wood ash composition and soil pH following intense burning. Soil Science 156, 358-364.

Ulery, A.L., Graham, R.C., Chadwick, O.A., Wood, H.B. 1995. Decade scale changes of soil carbon, nitrogen and exchangeable cations under chaparral and pine. Geoderma 65, 121-134.

Vasander, H., Lindholm, T. 1985. Fire intensities and surface temperatures during prescribed burning. Silva Fennica 19, 1-15.

Viro, P.J. 1974. Effects of forest fire on soil. In Fire and ecosystems, T.T. Kozlowski, C.E. Ahlgren (eds.), Academic Press, New York, NY.

Woods, S.W., Balfour, V.N. 2008. The effect of ash on runoff and erosion after a severe forest wildfire. International Journal of Wildland Fire 17, 535-548. 
Woods, S.W., Balfour, V.N. 2010. The effects of soil texture and ash thickness on the post-fire hydrological response from ash-covered soils. Journal of Hydrology 393, 274-286.

Zavala, L., Jordán, A., Gil, J., Bellinfante, N., Pain, C. 2009. Intact ash and charred litter reduces susceptibility to rain splash erosion post-wildfire. Earth Surface Processes and Landforms 34, 1522-1532.

Zavala, L.M., Granged, A.J.P., Jordán, A., Bárcenas-Moreno, G. 2010. Effect of burning temperature on water repellency and aggregate stability in forest soils under laboratory conditions. Geoderma 158, 366-374. 